J. Indian Chem. Soc.,

Vol. 80, December 2003, pp. 1111-1128

\title{
Role of amide and urea moieties in molecular recognition ${ }^{\dagger}$
}

\author{
Subodh Kumar*, Harjit Singh* and Rajan Sharma \\ Department of Chemistry, Guru Nanak Dev University, Amritsar-143 005, India \\ E-mail : harjitsingh@angelfire.com, subodh.kumar@angelfire.com Fax:91-183-258820
}

Manuscript received 17 October 2003

\begin{abstract}
The amide and urea moieties due to their unique stereoelectronic character interact with electron deficient centres through carbonyl group and with electron rich centers through $\mathrm{N}-\mathrm{H}$ units. This dual character has been successfully used for the design of urea/amide based receptors for recognizing variety of guests. This review discusses the salient examples of such receptors to bring out the unique scope of urea and amide units in designing receptors for recognition of cations, anions and neutral molecules.
\end{abstract}

Molecular recognition is quite essential to most of the biological and chemical processes. Enzymes, antibodies, membranes, and other receptors; carriers, and channels all involve molecular recognition as a key step in their biochemical functioning ${ }^{1}$. Molecular recognition in general involves multimolecular assemblies, called supramolecular complexes, formed between two or more topologically complementary chemical entities which are held together by non-covalent forces ${ }^{1,2}$. For a deep insight into the basis of noncovalent interactions and biological functions of receptors and to emulate the basic principles of nature, the investigations on complementarity of various host guest interactions in structurally simpler model receptors have been carried out. In fact the concept of molecular recognition grew out of such studies in the mid-sixties from the observations of selective recognition of alkali metal cations by ionophoric antibiotics $^{3-5}$ and synthetic macro(poly)cyclic polyethers ${ }^{6}$.

Molecular recognition character of a receptor is goverened by its overall structural topology where primarily the constituent functionalities trigger and influence the nature of its bindings. Amongst various functional groups such as ethers, thioethers, sulphides, disulphides, imines, amines, ureas and amides etc. used in the design of model receptors, amide and urea moieties enjoy a pre-eminent position because of their unique stereoelectronic character ${ }^{7}$. As depicted below amides elaborate electron rich $\mathrm{O}, \mathrm{N}$ centres and electron deficient $\mathrm{N}-\mathrm{H}$ units, and thus can bind with both electron deficient guests (at $\mathrm{O}, \mathrm{N}$ ) and electron rich guests through hydrogen bonding (at $\mathrm{N}-\mathrm{H}$ unit). Resonance assists amides to attainemore negative charge than any other neutral oxygen functionality and also provides desirable rigid spatial geometry. The spatial orientation of the amide could be effectively controlled by the bulk and nature of substituents on the amide nitrogen.

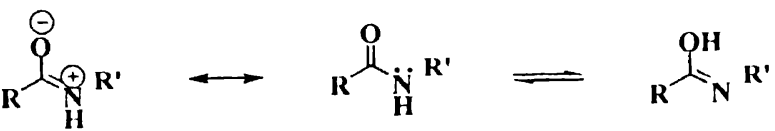

$$
\begin{aligned}
& \underset{\text { Urea }}{\text { Amide }} \underset{\mathbf{H}}{\mathrm{O}} \mathbb{N}^{\mathbf{R}^{\prime}}
\end{aligned}
$$

Urea moiety also owes its improtance to somewhat similar electronic character as the amide. Additional electron donation by the second nitrogen atom in the case of urea further increases the negative charge on the oxygen atom and provides rigidity to the geometry.

Nature has quite generously used amides in evolving receptors such as valinomycin ${ }^{3}$, baeuverici ${ }^{4}$, westiellamidie ${ }^{5}$ etc. and many other molecules of biological importance.

Importance of urea moiety in biological systems is quite evident from the fact that out of the five nucleobases, all three pyrimidine bases i.e. cytosine, thymine and uracil have urea moiety in their structure, which efficiently participates in double helix formation (H-bonds) and co-ordinates with metal ions ${ }^{8}$.

In this article, the unique role of amide and urea moieties in molecular recognition of both electron rich and electron deficient guests in synthetic receptors has been highlighted. The presentation is categorized into cationic, anionic and neutral recognition and in each category the receptors in order of podands, coronands, cryptands, cyclophanes and calixarenes etc. are arranged.

iDedicated to Professor S. M. Mukherji. 


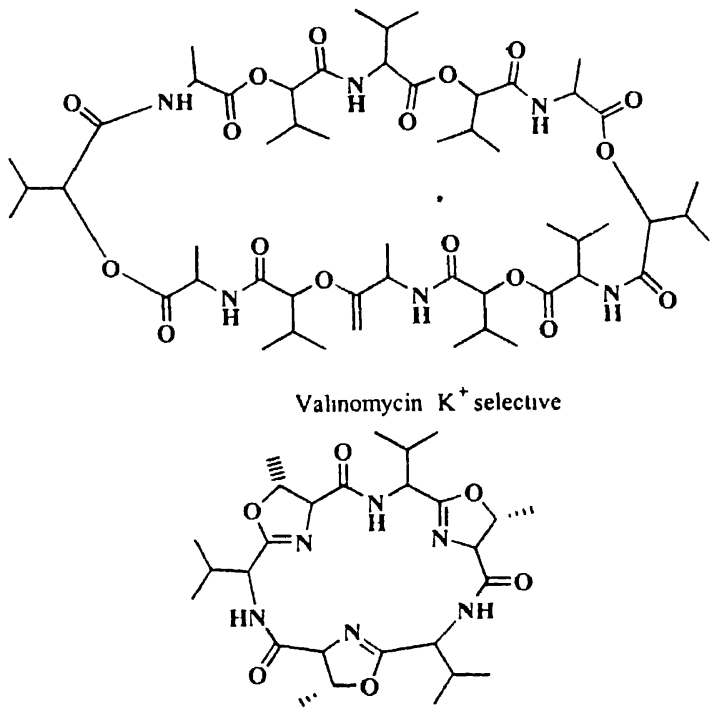

Westiellamide $\mathrm{Ag}^{+}$selective

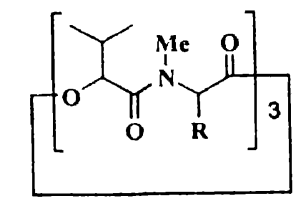

$\mathrm{R}=\mathrm{N}$-methyl-L-phenylalanıne Raeivencin $\mathrm{Ra}^{2+}$ selective

\section{I: Cationic recognition}

A pioneering effort to develop open chain amide based podands of utility in the development of ion selective electrodes was initiated by Simon and co-workers in Zürich and as early as $1972, \mathrm{Ca}^{2+}$ selective carrier $\mathbf{1}^{9}$ wasireported.

Numerous other ligands such as 2-5 were developed. From amongst a series of $N, N, N, N$-tetrasubstituted diamides, the ionophores $3 \mathbf{c}$ and $5 \mathbf{a}-\mathbf{c}$ showed a high $\mathrm{Li}^{+}$selectivity with $\mathbf{5 b}$ showing highest $\mathrm{Li}^{+}$selectivity over alkali (>1000 times) and alkaline earth (>100 times) cations. The ionophores $\mathbf{5 b}$ and $\mathbf{5 c}$ have been used for $\mathrm{Li}^{+}$assay determination $^{10-12}$.

Amongst podands $6-8,6 \mathrm{~b}$ co-ordinates with $\mathrm{Li}^{+}$ through four amide oxygens in a $2: 1$ (Ligand : $\mathrm{Li}^{+}$) complex. $\mathrm{Li}^{+}$selective electrodes based on ionophores $6 \mathbf{h}$, $8 \mathrm{a}, 8 \mathbf{b}, 8 \mathrm{~d}$ have also been reported ${ }^{13}$.

Amongst 3-oxapentanediamides 9-11, the compound 9d forms an ideal co-ordination sphere of nine atoms in 3 : 1 ligand- $\mathrm{Ca}^{2+}$ complex for the uptake of $\mathrm{Ca}^{2+}$ and in.duces a selectivity in membranes for $\mathrm{Ca}^{2+}$ over $\mathrm{Mg}^{2+}$,<smiles>CCOCCOCC(=O)N(C)CCC(=O)N(C)CCC(=O)OCC</smiles><smiles>[R3]N([R3])C(=O)C(=O)N([R3])[3H]</smiles><smiles>[10BH][10BH2]</smiles>

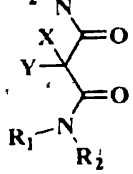

a X, $\mathrm{Y},=\mathrm{H}$

$\mathrm{R}_{1}=\mathrm{CH}_{3}$

$\mathrm{R}_{2}=\mathrm{n}-\mathrm{C}_{7} \mathrm{H}_{15}$

b X, Y, = H

$\mathrm{R}_{1}, \mathrm{R}_{2}=\mathrm{C}_{6} \mathrm{H}_{1}$

c $\mathrm{X}=\mathrm{H}, \mathrm{Y}=\mathrm{CH}_{3}$

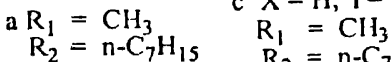
$\begin{aligned} R_{2}=n-C_{7} H_{15} & R_{1}=\mathrm{CH}_{2}=\mathrm{C}_{7} \mathrm{H}_{15} \\ \text { b } \mathrm{R}_{1}-\mathrm{R}_{2}=\mathrm{C}_{6} \mathrm{H}_{11} & \mathrm{R}_{2}\end{aligned}$

1

2

3

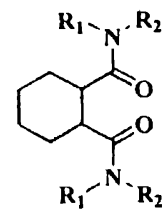

a $\mathrm{R}_{1}=\mathrm{CH}_{3}$

$\mathrm{R}_{2}=\mathrm{n}-\mathrm{C}_{7} \mathrm{H}_{15}$

$b R_{1}, R_{2}=$ isobutyl

$\mathrm{cR}_{1}=\mathrm{C}_{6} \mathrm{H}_{11}$

$R_{3}=$ isobutyl

5
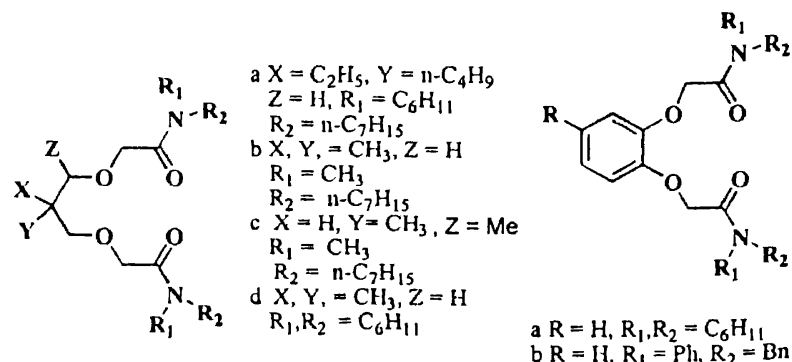

6

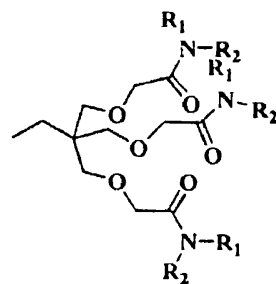

a $\mathrm{R}_{1}=\mathrm{CH}_{3}, \mathrm{R}_{2}=\mathrm{n}-\mathrm{C}_{7} \mathrm{H}_{1 \mathrm{~S}}$

$b \mathrm{R}_{1}, \mathrm{R}_{2}=\mathrm{C}_{6} \mathrm{H}_{11}$

$c R_{1}=P_{1}, R_{2}=B n$
$d R_{1}=C_{2} H_{5}, R_{2}=C_{6} H_{11}$ 
Kumar et al. : Role of amide and urea moieties in molecular recognition

$\mathrm{Na}^{+}$, and $\mathrm{K}^{+}$by a factor of $10^{4}, 10^{7.4}$ and $10^{8}$ respectively ${ }^{17}$. The IR monitored solubilization studies on complexes of a series of $N$-bridged benzimidazolones 12 with alkali and alkaline earth metal cations exhibit significant selectivity in complexation and transportation of $\mathrm{Ca}^{2+}$ in preference to the other cations ${ }^{18}$.

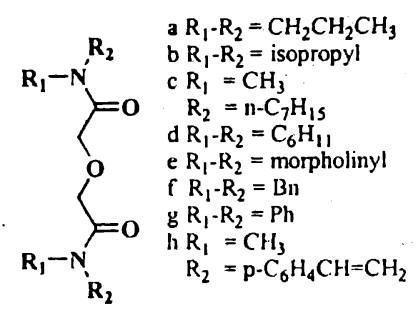

9

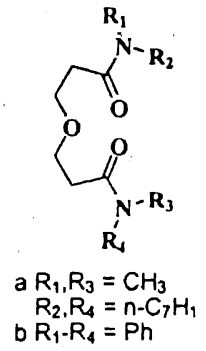

10<smiles>CCCN(CCC)C(=O)c1ccc(C(=O)N(CCC)CCC)o1</smiles>

11

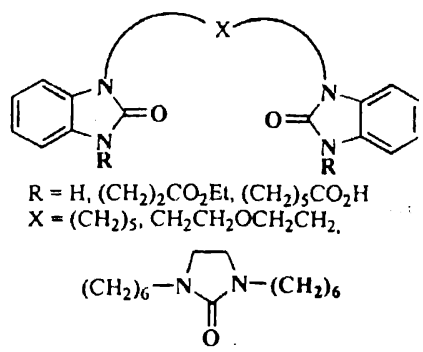

12

$N, N$ - $\mathrm{Di}(8$-quinolyl)malonamide derivative 13 selectively extracts $\mathrm{Cu}^{2+}$ amongst the transition metal ions from the aqueous phase. However, $\mathbf{1 4}$ hardly extracts any metal ion but effectively transports $\mathrm{Cu}^{2+}$ with high selectivity through liquid membranes ${ }^{19}$, whereas 13 exhibits poor transport character probably due to high binding ability. The $N$-benzyloxyamide derivatives $\mathbf{1 5}$ and $\mathbf{1 6}$ selectively formed complexes with $\mathrm{Hg}^{2+}$. Podand $\mathbf{1 5}$ can be used as ionophore for ion selective electrodes to detect $\mathrm{Hg}^{2+}$ with good reproducibility ${ }^{20,21}$. Podand $\mathbf{1 6}$ formed stable complexes accompanied by deprotonation of the amide groups only when $\mathrm{Hg}^{2+}$ was added.

Amongst the amide functionalised macrocyclic tweezer shaped coronands, the receptor 17 a displays significant

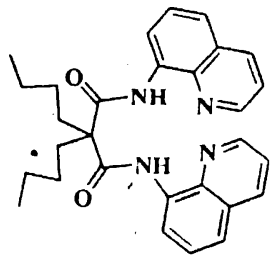

13

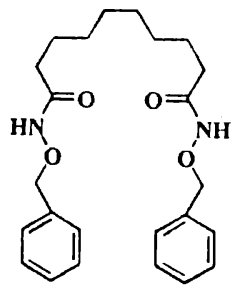

15

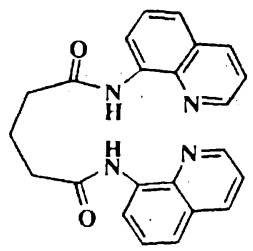

14

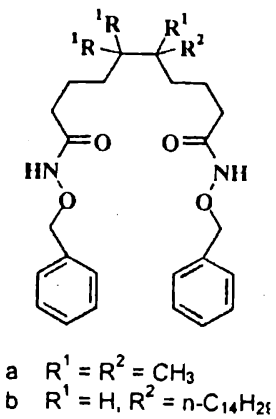

16 selectivity for $\mathrm{Li}^{+}$over $\mathrm{Na}^{+}$in polymeric membranes ${ }^{22}$. The optically active macrocycles 18 incorporating both ester and amide functionalities have been synthesized to mimic the highly selective binding character of natural ionophores ${ }^{23}$. Thus the 24-membered $18(n=1, m=3)$ mimics valinomycin in its ability to transport $\mathrm{K}^{+}$and $\mathrm{Na}^{+}$ions. Meso $18(n=1$, $m=3)$ is more efficient than ( \pm$) \mathbf{1 8}(n=1, m=3)$ for the transport of alkali metal cations $\left(\mathrm{Na}^{+}, \mathrm{K}^{+}, \mathrm{Rb}^{+}, \mathrm{Cs}^{+}\right)$but both exhibit negligible transport of alkaline earth $\left(\mathrm{Ba}^{2+}\right.$, $\mathrm{Sr}^{2+}, \mathrm{Mg}^{2+}$ and $\mathrm{Ca}^{2+}$ ) picrates.

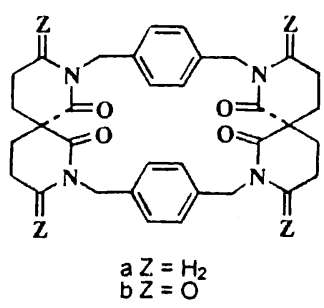

17

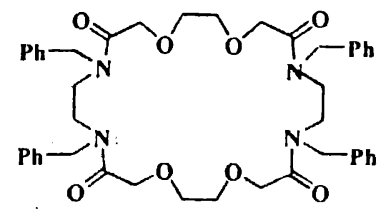

19

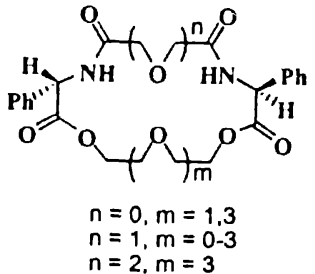

18

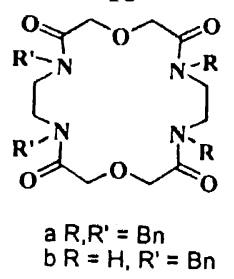




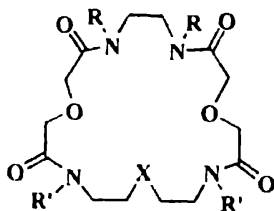

a $R, R^{\prime}=\mathrm{Bn}, X=\mathrm{N}-\mathrm{C}_{6} \mathrm{H}_{5}$ b R, $R^{\prime}=\mathrm{Bn}, X=\mathrm{N}-\mathrm{C}_{6} \mathrm{H}_{4} \mathrm{~F}-\mathrm{p}$ c $R=H, R^{\prime}=B n, X=N-C_{6} H_{5}$ $d R, R^{\prime}=B n, X=0$

21

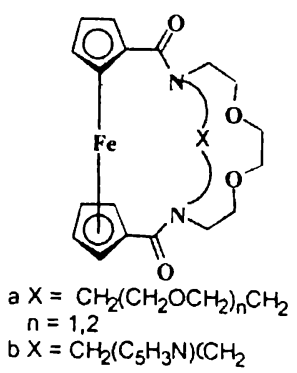

22
For similar lipophilicity but lower number of binding sites and smaller ring size, 20a extracts alkaline earth metal picrates better than the more flexible 19 in the order $\mathrm{Ba}^{2+} \sim$ $\mathrm{Sr}^{2+}>\mathrm{Ca}^{2+}$ but 20b shows higher selectivity in extraction for $\mathrm{Ba}^{2+}$ ions ${ }^{23}$. Both 20a and 20b furnish 1: 1 complexes with $\mathrm{Ba}^{2+}$ picrate ${ }^{24}$. However, the increase in the ring size in 21a, 21b over that of 20a reveals order $\mathrm{Ca}^{2+} \sim \mathrm{Sr}^{2+}>$ $\mathrm{Ba}^{2+}$ but $21 \mathrm{c}$ is selective for $\mathrm{Ba}^{2+}$ over $\mathrm{Ca}^{2+}$ and $\mathrm{Sr}^{2+}$ ions ${ }^{25}$.

Ferrocene containing unsymmetrical cryptand 22a $(n=$ 1) employs carbonyl oxygens in binding to di and trivalent metal ions ${ }^{26 a}$. The 22a $(n=2)$ gives 2: 1 (host-guest) complex with an yttrum cation ${ }^{26 b}$. The ferrocenophane 22b contaıning a pyridine unit, forms complexes with a series of guest cations $\left(\mathrm{Na}^{+}, \mathrm{Ca}^{2+}, \mathrm{Ba}^{2+}\right.$ or $\left.\mathrm{Y}^{3+}\right)$.

Macrocycles 23 and 24 with amine-amide combination undergo deprotonatıon at amide $\mathrm{NH}$ with divalent transition metal ions to form neutral complexes.

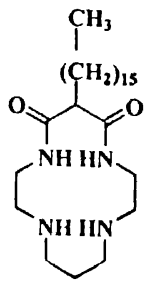

23

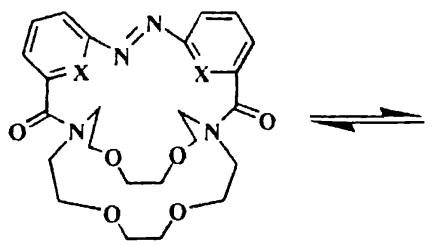

25 (E) $\mathrm{X}=\mathrm{CH}$

26 (E) $x=N$

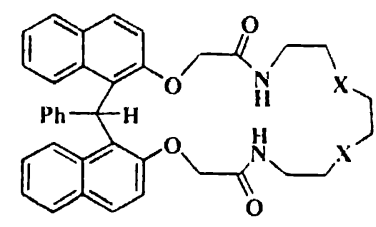

$x=\mathrm{NH}, \mathrm{O}$
The ionophore $\mathbf{2 3}$ acts as a carrier for proton coupled transport of $\mathrm{Cu}^{2+}$ against concentration gradient ${ }^{27}$. Ligand
$24(\mathrm{X}=\mathrm{NH}, \mathrm{O})$ transports $\mathrm{Pb}^{2+}$ and $\mathrm{Ag}^{+}$picrates rejecting alkali metal picrates ${ }^{28}$.

Lignad 25(E) having photosensitive azobenzene cap shows selective binding to $\mathrm{Na}^{+}$while $25(Z)$ formed by photomerization, encapsulates $\mathrm{K}^{+}$more strongly suggestıng the expansion of $\mathrm{N}_{2} \mathrm{O}_{4}$ ring photoinduced by $(E)$ to $(Z)$ isomerization ${ }^{29}$. The ligand $\mathbf{2 6}$ in which azobenzene cap is replaced by pyridine unit, strongly binds to heavy metal cations particularly $\mathrm{Cu}^{2+}$ and no such binding is encountered in $\mathbf{2 6}(Z)^{30}$.

Amide functionalized appendages to the macrocyclic backbone also influence the binding character. Among the series of chiral mono- and di-substituted 14-crown-4 derivatives, the macrocycles $27 \mathbf{a}$ and $\mathbf{2 7} \mathbf{b}$ with amides as appendages induce the best $\mathrm{Li}^{+}$to $\mathrm{Na}^{+}$selectivity $(630: 1)$ in liquid membrane electrodes ${ }^{31}$.

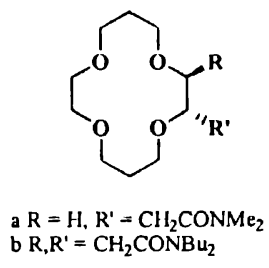

27

In ligand $\mathbf{2 8}$ though amide groups do not participate in complexation but position the two 15-crown-5 units to form $1: 2$ host-guest complex with $\mathrm{Na}^{+}$and $1: 1$ complexes with $\mathrm{K}^{+}, \mathrm{Rb}^{+}, \mathrm{Cs}^{+}$and $\mathrm{NH}_{4}^{+}$ions. The ligand reveals high selectivity for $\mathrm{K}^{+}$over other cations ${ }^{32}$.<smiles>COc1c(C(=O)Nc2ccc3c(c2)OCCOCCOCCOCCO3)cc(C)cc1C(=O)Nc1ccc2c(c1)OCCOCCOCCOCCO2</smiles>

A series of ether-ester macrocycles and podands containing one or two cyclic urea oxygens show selective extraction of $\mathrm{Sr}^{2+}$ picrate ${ }^{33}$ over $\mathrm{Li}^{+}, \mathrm{Na}^{+}, \mathrm{K}^{+}, \mathrm{Tl}^{+}, \mathrm{Mg}^{2+}$ and $\mathrm{Ca}^{2+}$ picrates with macrocycle 29 showing maximum selectivity. Macrocycles 30a and 30b selectively extract lead picrate over silver, alkali and alkaline earth metal picrates ${ }^{34}$. Pyridine based diamide-diester 18-membered macrocycle 31 
extracts $\mathrm{Ag}^{+}$picrate with remarkable selectivity over alkali, alkaline earth, $\mathrm{Tl}^{+}$and $\mathrm{Pb}^{2+}$ picrates ${ }^{35}$.<smiles>O=C(O)CCN1CCN(CCC(=O)OCCOCCO)C1=O</smiles>

29

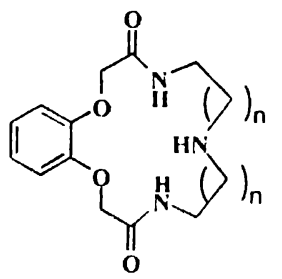

$a n=1$
$b n=2$

30<smiles>CC(=O)NCCOC(=O)c1cccc(C(=O)OCCNC(=O)c2cccc(C(C)(C)C)n2)n1</smiles>

31

Octamides 32 of $p$-alkoxycalix [8]arenes extract alkaline earth metal picrates from water to dichloromethane, and the corresponding nitrates from acidic water solution simulating radioactive waste to 2-nitrophenyl hexyl ether (NPHE) ${ }^{36}$. In case of simulated waste solutions, the distribution coefficients for strontium removal by octamides are much higher than the corresponding value found for dicyclohexyl-18crown-6 (DC18C6). Amongst various heterocalix [6]arenes with different number of uracil and benzimidazolone units and three aryl units, the heterocalix[6]arene 33 exhibits $t$ $\mathrm{BuNH}_{3}{ }^{+} / \mathrm{K}^{+}$selectivity ${ }^{37}$.

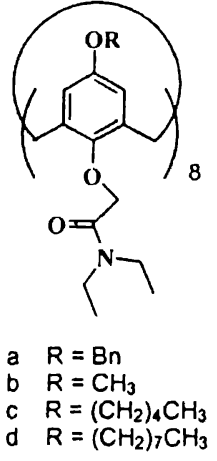

32<smiles></smiles>

33
Tetraamide $\mathbf{3 4}$ in its partial cone conformation forms a $1: 1$ complex with lanthanum picrate ${ }^{38}$ through three amide and two etheral oxygens co-ordination. The cyclophane 35 with amine, carboxylate and amide as three electron donor

groups complexes with $\mathrm{Ni}^{2+}, \mathrm{Cu}^{2+}$ and $\mathrm{Zn}^{2+} .39$.

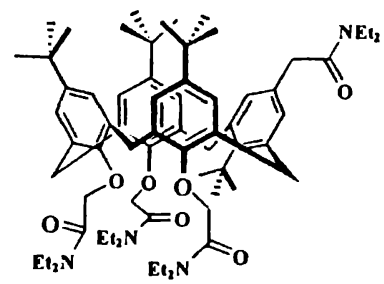

34

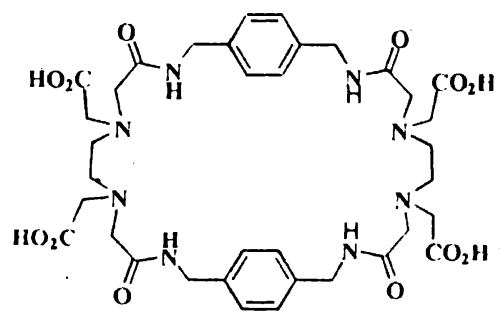

35

A cyclic pseudo-peptide receptor 36 has been isolated from a combinatorial library which shows a binding towards $N$-methylammonium salts ${ }^{40}$.

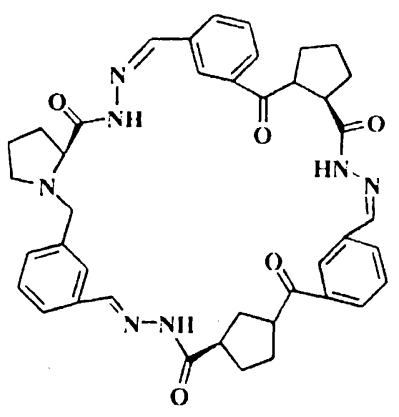

36

Carboxamido nitrogens may be used in the synthesis of different receptors for binding $\mathrm{Fe}^{3+}$ ion. Thus the compounds 37-42 are used for the synthesis of the $\mathrm{Fe}^{\mathrm{III}}$ complexes $^{41}$.

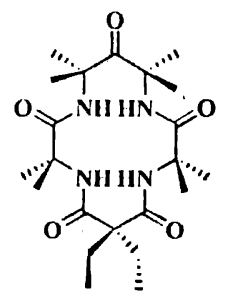

37<smiles>C=C1NC(=O)C(CC)(CC)C(=O)N[C@@](C)(CC)C(=O)Nc2cc(Cl)c(Cl)cc2N1</smiles>

38 


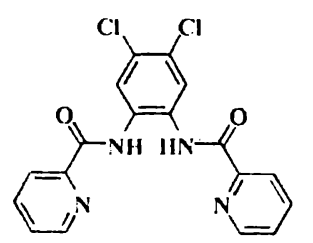

39<smiles>[X]c1ccccc1NC(=O)c1ccccn1</smiles>

41<smiles>[Y]#N</smiles>

40<smiles>[X]c1ccccc1NC(=O)c1cccc(C(=O)Nc2ccccc2[X])n1</smiles>

42
More recently, receptors have been appended with appropriate fluorescent moieties and the change in fluorescence during complexation provides direct means of both qualitative and quantitative estimation of guest species. The solution of $43^{42}$ in acetonitrile-water at $\mathrm{pH} 7.1$ adjusted with 2,6-lutidine shows fluorescence quenching on addition of $\mathrm{Cu}^{2+}$ whereas no decrease in fluorescence is observed with $\mathrm{Ni}^{2+}, \mathrm{Mn}^{2+}$ and $\mathrm{Co}^{2+}$ cations.

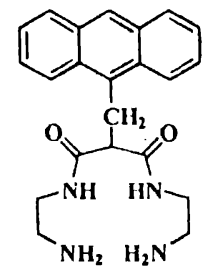

43

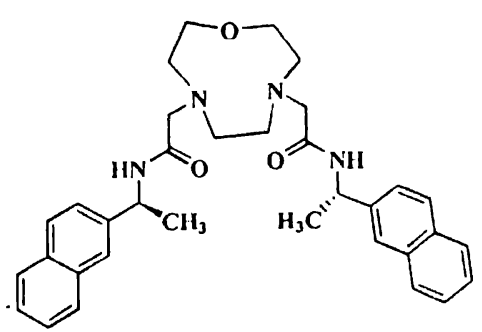

44
The chiral diaza-9-crown-3 derivative 44 displays "offon" switching ${ }^{43}$ of fluorescence when treated with various lithium salts in organic solvents such as $\mathrm{CH}_{3} \mathrm{CN}$ and discriminates against a variety of group I and group II metal ions.

The optically ${ }^{44}$ active cyclic hexapeptides $45 \mathrm{a}$ and $45 \mathrm{~b}$ exhibit intense pyrene monomer emission at $375-418 \mathrm{~nm}$ and an additional pyrene excimer band at $487 \mathrm{~nm}$ (intramolecular) in 45a and $481 \mathrm{~nm}$ (intermolecular) in 45b. The addition of $\mathrm{Ca}^{2+} / \mathrm{Ba}^{2+}$ perchlorate to a solution of cyclic peptide 45 a causes a considerable increase of the excimer to monomer emission ratio $\left(I_{\mathrm{e}} / I_{\mathrm{m}}\right)$ which is more pronounced in case of $\mathrm{Ca}^{2+} . \mathrm{Mg}^{2+}$ does not affect the emission of $45 \mathrm{a}$. Peptide 45b shows analogous fluorescence characteristics but $I_{\mathrm{e}} / I_{\mathrm{m}}$ ratio is much lower in comparison to that observed in $45 \mathrm{a}$.

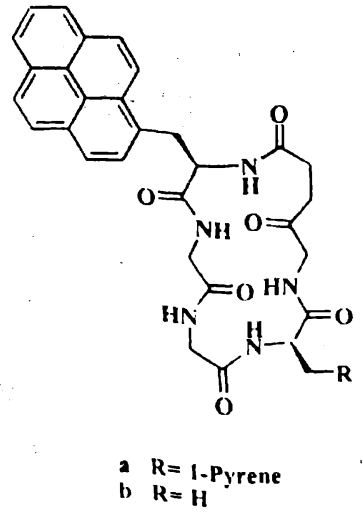

45

Ureyleno crown ether $46^{45}$ binds with 2 equivalent of $\mathrm{Li}^{+}$co-operatively and selectively $\left[K=3 \times 10^{7} \mathrm{dm}^{3} \mathrm{~mol}^{-1}\right]$ over other alkali metal ions such as $\mathrm{Na}^{+}, \mathrm{K}^{+}$and $\mathrm{Cs}^{+}$.
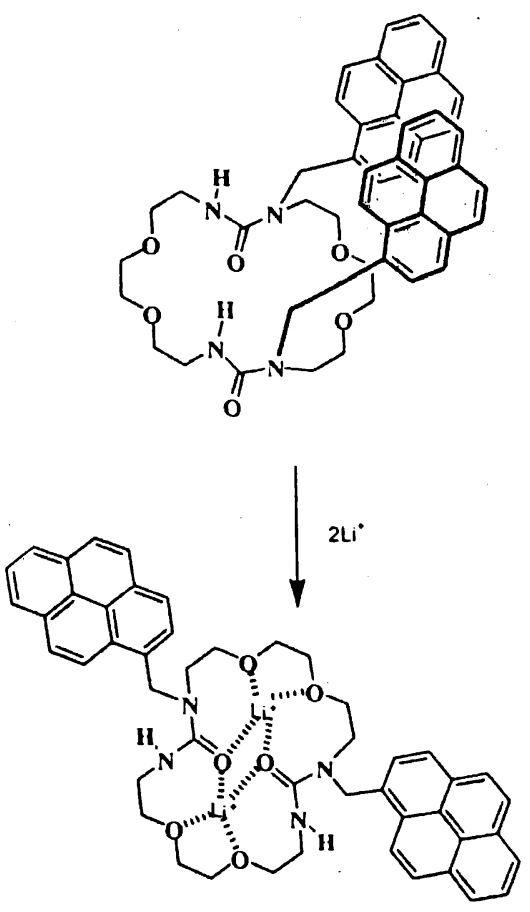

46

The calix[4]arene $47^{46}$ shows fluorescence enhancement with $\mathrm{Zn}^{2+}$ but fluorescence quenching with $\mathrm{Ni}^{2+}$.

\section{Anionic recognition}

Anions are larger in size than isoelectronic cations (Table 1) and therefore have a lower charge to radius ratio. This causes lower electrostatic binding interactions and lower 
Kumar et al. : Role of amide and urea moieties in molecular recognition

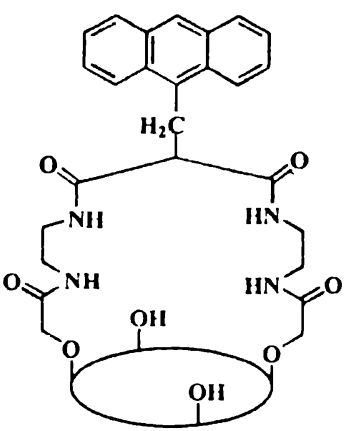

47

binding in case of anion receptors than observed for the cation receptors.

\begin{tabular}{|c|c|c|c|}
\hline Cation & $r[\AA]$ & Anion & $r[\AA]$ \\
\hline $\mathrm{Na}^{+}$ & 1.16 & $\mathrm{~F}^{-}$ & 1.19 \\
\hline $\mathrm{K}^{+}$ & 1.52 & $\mathrm{Cl}^{-}$ & 1.67 \\
\hline $\mathrm{Rh}^{+}$ & 1.66 & $\mathrm{Br}^{-}$ & 1.82 \\
\hline $\mathrm{Cs}^{+}$ & 1.81 & $\mathrm{I}^{-}$ & 2.06 \\
\hline
\end{tabular}

Additionally, anions are more sensitive to the $\mathrm{pH}$ (becoming protonated at lower $\mathrm{pH}$ ), and therefore receptors must function within the $\mathrm{pH}$ range of the target anion. Anionic species have wide range of geometries and therefore a higher degree of design may be required to make receptors complementary to their anionic guest. Anionic receptors involving varied non-covalent interactions viz. electrostatic interactions, hydrogen bonding, hydrophilicity, co-ordination to a metal ion, and combination of these interactions have been developed. Receptors which use the amide moiety for bindIng anions, make use of the hydrogen bonds. Being directıonal in nature, hydrogen bonds allow the designing of receptors with specific shapes capable of differentiating anionic guests with different geometries.

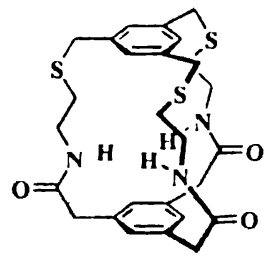

48

In 1986, Pascal prepared the first purely amide based anion receptor $48^{47}$ which binds fluoride ion in [D6]DMSO. In 1993 Reinhoudt and co-workers produced a series of acy- clic tripodal receptors containing amide groups $49-54^{48}$ whereas Raposo et al. synthesized a preorganized and extended amide embroided cyclohexane ring derived receptor $55^{49}$.

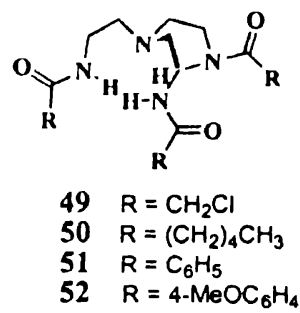

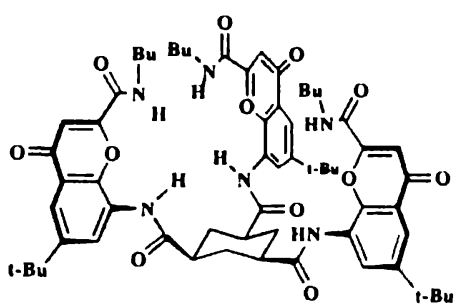

55

Receptors 49-55 are all C3-symmetric and are consequently organized to bind tetrahedral anions. Anslyn and co-workers have reported the synthesis of a cage like molecule $\mathbf{5 6}{ }^{50}$. Since the amide $\mathbf{N H}$ groups in $\mathbf{5 6}$ are arranged in a trigonal prismatic array, they are able to co-ordinate to the $\pi$-electron system of planar anions such as carboxylates and nitrate.

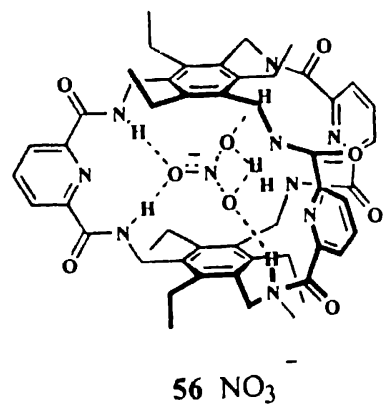

Ureas and thioureas are particularly good hydrogen bond donors and are excellent receptors for $\mathrm{Y}$-shaped anions such as carboxylates through the formation of two hydrogen bonds. The urea based receptor $\mathbf{5 7}$ forms highly stable complexes with bidentate ligands 51 .

The acyclic cleft molecules ${ }^{52} 58$ and 59 bind anions very strongly with stability constants upto $19500 \mathrm{M}^{-1}$ for receptor 59 and $\mathrm{H}_{2} \mathrm{PO}_{4}^{-}$ions in [D6]DMSO. The selectivity for $\mathrm{H}_{2} \mathrm{PO}_{4}^{-}$ions can be attributed to the complementary hydro- 


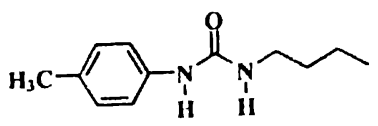

57

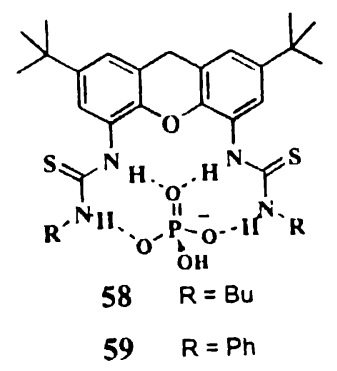

gen bonding array present in these clefts that can form four hydrogen bonds to each $\mathrm{H}_{2} \mathrm{PO}_{4}^{-}$ion.

Ferrocene units appended with secondary amides have also been used for anion recognition ${ }^{53,54}$. For example, 6063 were capable of detecting $\mathrm{H}_{2} \mathrm{PO}_{4}^{-}$ions in the presence of a ten-fold excess of $\mathrm{HSO}_{4}^{-}$and $\mathrm{Cl}^{-}$ions in acetonitrile as shown by large cathodic shifts of upto $240 \mathrm{mV}$.

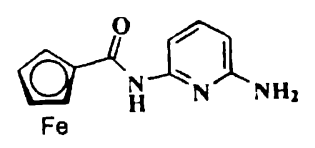

Q

60

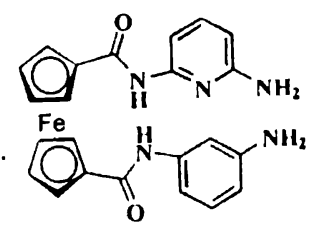

61

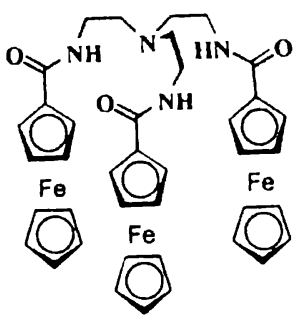

62

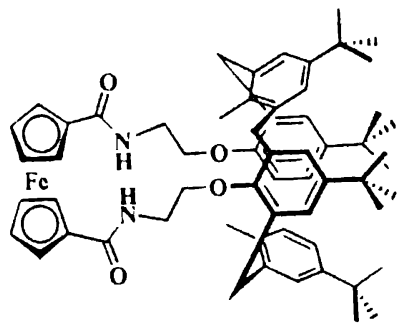

63
In evolving amide based anion receptors tris $\left(2,2^{\prime}\right.$ bipyridyl)ruthenium(II) $\left(\left[\mathrm{Ru}(\mathrm{bpy})_{3}\right]^{2+}\right)$, because of its chemical stability, redox properties, excited-state reactivity, and luminescent emission ${ }^{55}$ had been one of the most extensively investigated platforms. Beer and co-workers have incorporated this moiety into acyclic, macrocyclic, and calix[4]arene structural frameworks to produce new class of anion receptors 64-68 capable of optical and electorchemical sensing ${ }^{56-58}$.

Watanabe $e t$ al. has produced imidazole-functionalized ruthenium-bipyridyl complexes such as 69 which recognizes anionic and neutral phosphodiesters with luminescent signal enhancement observed for anionic phosphodiesters in acetone ${ }^{59}$. Similar complexes have been proposed to be
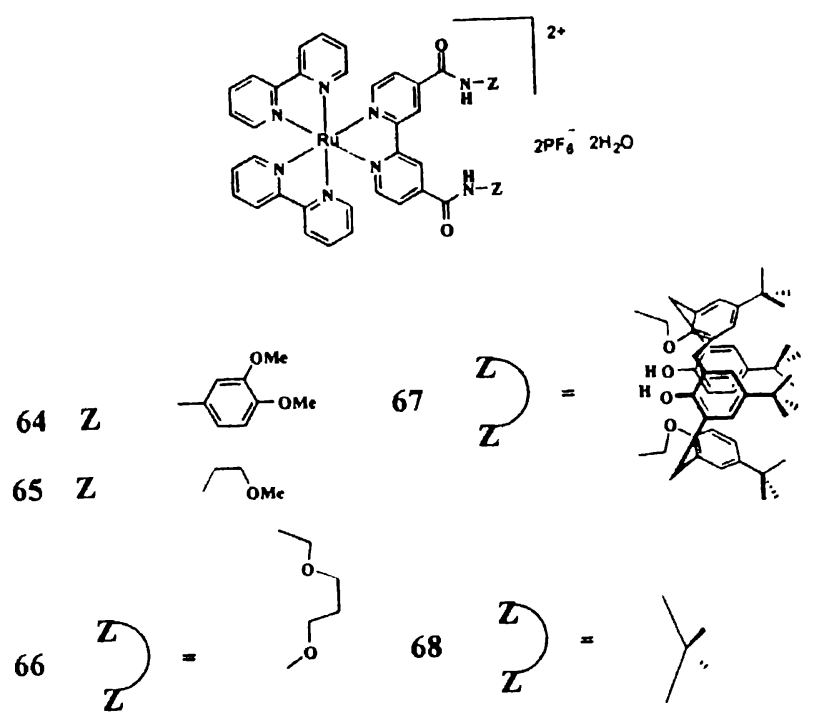

formed between 69 and tetraethylammonium diphenyl phosphate (TDPP) or dibenzylphosphate (DBHP).

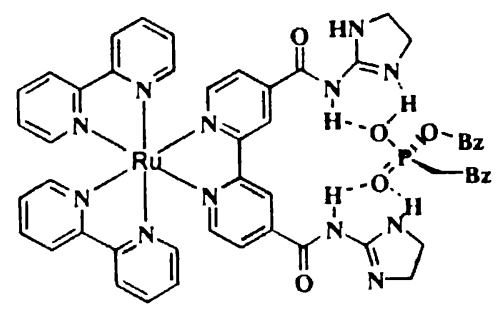

69 DBHP

Ruthenium(II)- and rthenium(I)-bipyridylcalix [4] diquinone receptors $\mathbf{7 0}$ and $\mathbf{7 1}$ selectively bind and sense acetate ion through remarkable retrievel effects of luminescent emission intensity ${ }^{60}$.
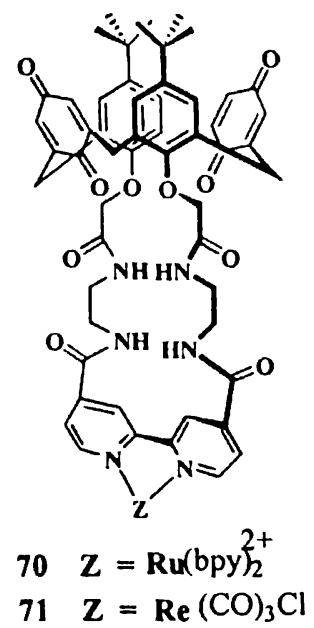
Kumar et al. : Role of amide and urea moieties in molecular recognition

Diamides $\mathbf{7 2}$ are readily synthesized and are found to bind strongly to the acetate and halides in organic solvents ${ }^{61}$.

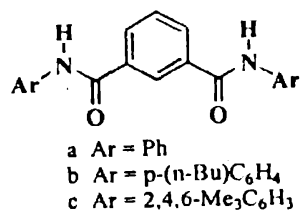

72

A structurally designed strategy for improving the binding ability of neutral urea and amide based receptors had been described ${ }^{62}$. A series of boronate ureas 73 and a related bis(boronate-amide), $\mathbf{7 4}$ were prepared. Their enhanced binding towards carboxylate anions is explained due to the co-operative polarization effect which is induced by intramolecular co-ordination of urea or amide carbonyl to a Lewis acidic boronate group.

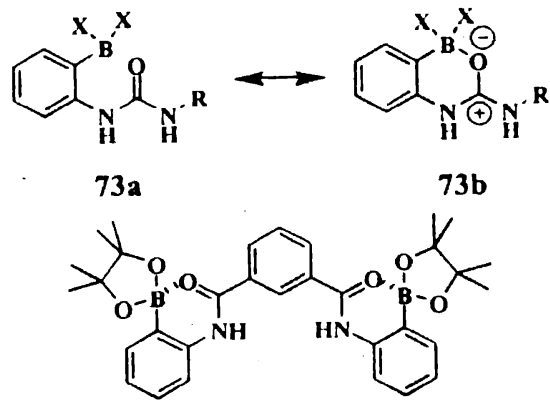

74.

Beer and co-workers have synthesized some tripodal tris-

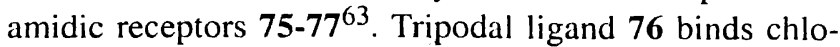
ride, iodide, and perrhenate anions via co-bound crown ether and efficiently extracts and transports the perrhenate $\left(\mathrm{ReO}_{4}^{-}\right)$ anion from simulated aqueous nuclear waste solution via co-operative ion-pair binding effect.<smiles>[Z]C(=O)CN(CCNC([Z])=O)CCNC(C)=O</smiles>

75<smiles>COc1ccc(C)cc1OC</smiles>

76<smiles>Cc1ccc2c(c1)OCCOCCOCCOCCO2</smiles>

$77 \mathrm{Z}=$<smiles>CCCCCCC</smiles>

The co-ordination of four $n$-butylnicotinamide ligands to a platinum(II) centre provides a facile method of organizing amide $\mathrm{H}$-bond donors for anion binding; the $\mathrm{PF}^{=}=$complex 78 is an effective receptor for a variety of oxo-anions ${ }^{64}$.

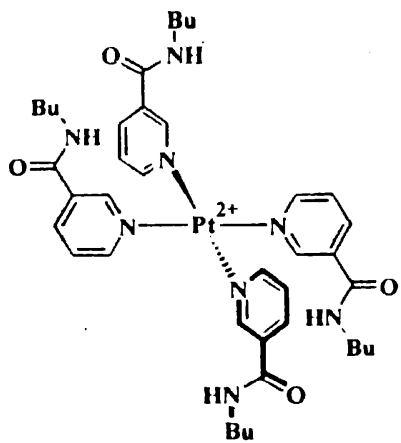

78

Different 2,2'-biimidazoles 79a-f with various amide groups at the position 4- and 4'- exhibit quenching in emission intensity in the presence of $\mathrm{H}_{2} \mathrm{PO}_{4}^{-}$and $\mathrm{Cl}^{-}$. The binding constants for $1: 1$ biimidazole-anion complexation are $10 \mathrm{M}^{-1}$ for $\mathrm{H}_{2} \mathrm{PO}_{4}^{-}$and $\mathrm{Cl}^{-65}$.

Simple 2,5-diamidopyrroles such as $\mathbf{8 0}$ and $\mathbf{8 1}$ function as oxo-anion selective receptors in acetonitrile- $d_{3}$ and DMSO- $d_{6} 0.5 \% \mathrm{H}_{2} \mathrm{O}$ solutions ${ }^{66}$.<smiles>[R]C(=O)C1=C(CCC)C(=N)C(c2nc(C([R])=O)c(CCC)[nH]2)=N1</smiles>

(a)

(b)<smiles></smiles>

(d) $\mathrm{R}=\mathrm{NN}$

(e) $\mathrm{R}=\mathrm{HN} \widehat{\mathrm{O}}^{\prime}$

(f) $\mathbf{R}$
79 a-f
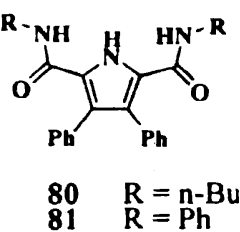

Amongst different amine, ammonium, and amide pendant arm diamidopyrroles $\mathbf{8 2 - 8 4}$, the receptor 82 binds 
strongly with $\mathrm{HSO}_{4}^{-}$. This strong binding is attributed to the protonation of the receptor by the anion. Evidence to this fact is given by the fact that $\mathbf{8 4}$ has a lower affinity constant for $\mathrm{HSO}_{4}^{-}$, as protonation is not possible in this case. Receptor 83 shows enhanced binding with halide ions in comparison to 82 reflecting the extra electrostatic component to the binding interactions ${ }^{67}$.

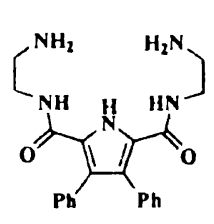

82
83

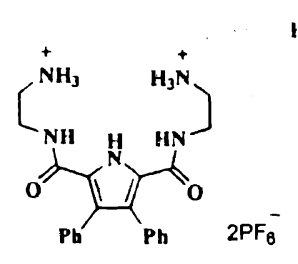

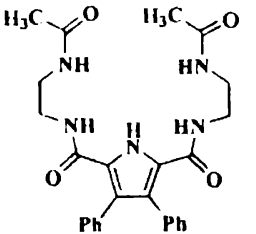

84.
The colorimetric anion sensor $\mathbf{8 5}$ allows for the naked eye differentiation ${ }^{68}$ of $\mathrm{F}^{-}, \mathrm{AcO}^{-}$, and $\mathrm{H}_{2} \mathrm{PO}_{4}^{-}$. The association of 85 with various polar solvents such as DMSO- $d_{6}$ and $\mathrm{CD}_{3} \mathrm{CN}$ was studied by NMR. The selectivities trends of 85 with DMSO- $d_{6}$ were : $\mathrm{F}>>\mathrm{AcO}^{-}>\mathrm{H}_{2} \mathrm{PO}_{4}{ }^{-}>\mathrm{HSO}_{4}{ }^{-}$ $\mathrm{Cl}^{-} \sim \mathrm{Br}^{-}$.

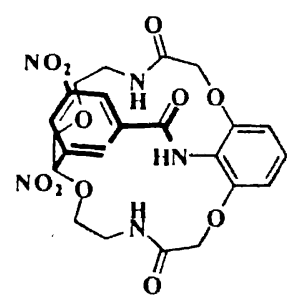

85

$\mathrm{C}_{3}$ symmetric macrocyclic anion receptor 86 binds tetrahedral anions such as sulphate and phosphate with high affinity. Titration of $\mathbf{8 6}$ with tosylate anion as its tetrabutylammonium salt gave $1: 1$ binding isotherms for amide and aryl protons of $\mathbf{8 6}$.

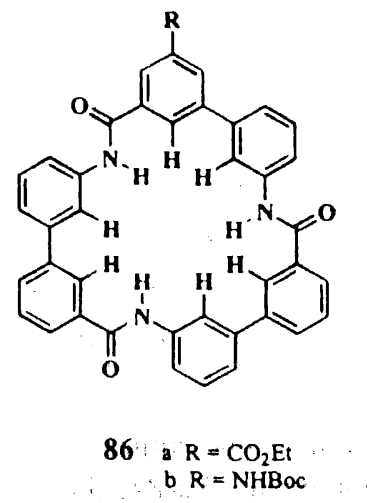

\section{Neutral molecular recognition}

The interactions between a neutral (usually organic) molecular guest and the host framework may vary from very limited (e.g. van der Waals interactions) to significant stability (e.g. hydrogen bonds). Unlike charged species, neutral molecules are neither bound by strong permanent electrostatic forces, nor do they undergo well-defined co-ordination interactions, and hence their bindings are weaker. Also the sizes of the neutral guests are larger than metal cations or simple anions. Despite these features, the importance of this phenomenon in biological systems has lead to an enomous diversity of hosts or lattice compounds, which can bind neutral molecules through $\mathrm{H}$-bonding ${ }^{70-76}$.

Hydrogen bonds are simulated in molecular mechanics as attraction between the bridge-forming proton and the donor and acceptor hetero element bearing negative partial charges. Many supramolecular systems have been devised which are based essentially on the simultaneous action of properly arranged hydrogen bond donors and acceptors. Amides because of facility of their modification and lipophilicity have been widely used as $\mathrm{H}$-bond donors.

In combination with pyridine group, receptor 87 prepared by Hamilton and co-workers ${ }^{77}$ complexes glutaric acid with $K=6.4 \times 10^{2} \mathrm{M}^{-1}$ in THF-CDCl 3 in an enthalpy driven process.

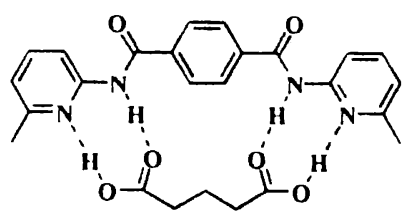

87

Cyclic hexaamides 88 where the skeleton is stiffened by three $p$-phenylene spacer units and cavity diameter approaches that of small cyclodextrins, showed affinity to haloforms and some other molecules in organic solvents ${ }^{78}$.

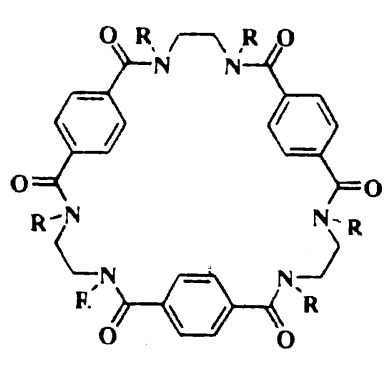

88 (a) $\mathrm{R}$

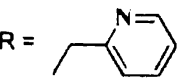

(b) $\mathrm{R}=$

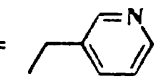

(c) $R=$

(d) $R=\quad \mathrm{Me}$

(e) $\mathrm{R}$

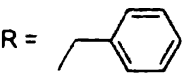


Kumar et al. : Role of amide and urea moieties in molecular recognition

Systems 89 possessing six-basic heteroarenes are tailor-made for encapsulating sterically and functionally complementary trihydroxybenzene ${ }^{79}$. Such hosts are sensitive to the introduction of methyl or ammonium groups into the guest molecules as 2,4,6-trihydroxytoluene or 2,4,6trihydroxytoluene hydrochloride are not complexed. The more strongly acidic nitrophloroglucinol simply forms, like picric acid, $1: 3$ complexe.

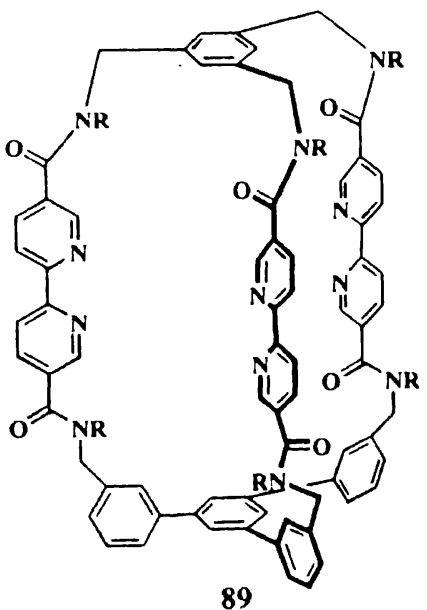

In contrast to the tris(bipyridine)hosts, the macrobicyclic ligand 90 has pronounced proton donor character, due to six hydroxyl groups of the catechol units. As a consequence, it complexes organic molecules with basic functional groups as long as the $\mathrm{p} K_{\mathrm{S}}$ and $\mathrm{p} K_{\mathrm{B}}$ values are mutually compatible $^{80}$. Strongly basic triamines, form salt like aggregates by an acid-base reaction. Purine, pyrimidine and other less basic compounds are solubilised by 90 in dichloromethane in which they are otherwise sparingly soluble.

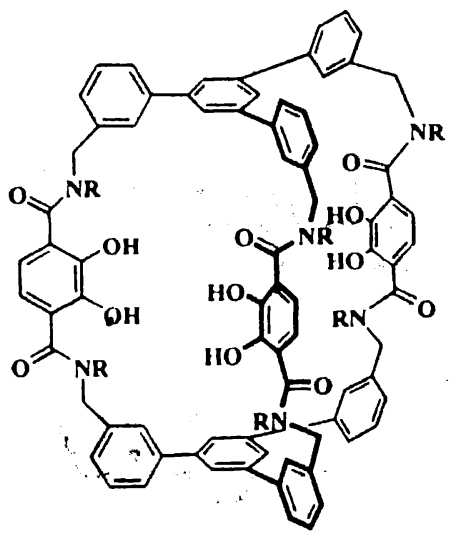

90
The macromonocyclic bis(catechol) host $91^{80}$ constitutes a hydrogen bond receptor for piperazine-type guest molecules in organic solution and association for guests 92 (piperazine) and 93 (1,4-diazacycloheptane) are around $10^{2}$ $\mathrm{M}^{-1}$. Extraction and transport studies show that host 91 is quite efficient in binding nucleic bases too.

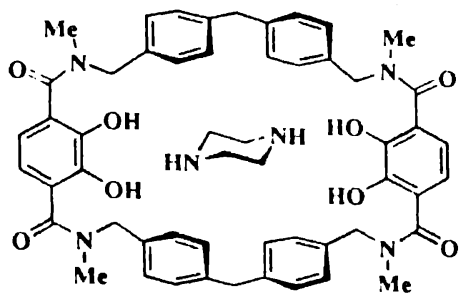

91 piperazine-complex<smiles>C=C1CCN(C)CC1</smiles><smiles>C=C1CCCN(C)CC1</smiles>

92

93

The basket shaped molecule 94 in $\mathrm{CDCl}_{3}$ solubilizes ammonium $p$-nitrophenolate by the formation of the complex ${ }^{81}$.

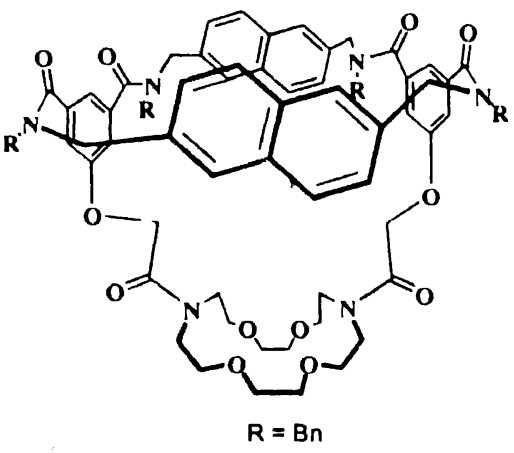

94

The macrobicyclic hosts 95 and $96^{82}$ employ multiple hydrogen bonds to bind organic guests with donor and acceptor functionalities arranged in a manner complementary to the cyclourea units and amide groups of the molecular cavities ${ }^{83,84}$. Binding energy for the complex of 4-pyridone and 95 is approximately $-21 \mathrm{~kJ} \mathrm{~mol}^{-1}$. Potential guests such as pyridine or $\mathrm{N}$-substituted imidazoles are discriminated, 
since they do not possess proton donor properties.

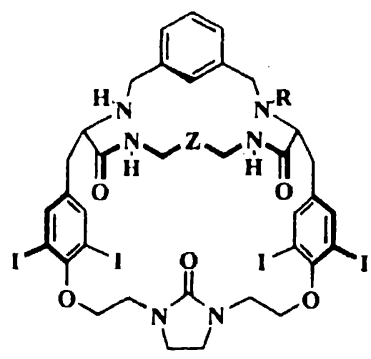

$95 \mathrm{Z}=\mathrm{CH}_{2}, \mathrm{R}=\mathrm{H}$

$96 \quad \mathrm{Z}=\mathrm{m}$-phenylene, $\mathrm{R}=\mathrm{Bn}$

The water soluble macrobicyclic compound $97(\mathrm{R}=\mathrm{Me})$ constitutes a ditopic host for zwitterionic amino $\mathrm{acid}^{85}$ and binds $\gamma$-aminobutyric acid (GABA) with an association constant of $3.2 \times 10^{3} \mathrm{M}^{-1}\left(\mathrm{D}_{2} \mathrm{O}\right)$. Glycine, which is too small, and 6-aminocaproic acid, which is too large, are only weakly bound.

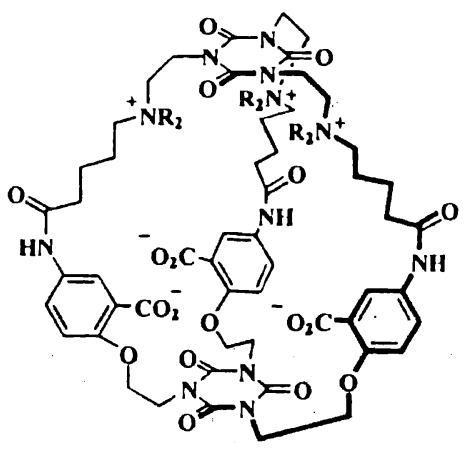

97.

Macrobicyclic host $98^{86}$ complexes flat, disk shaped aromatic guest pyrene in aqueous phase ${ }^{87}$. Several macrocyclic hosts such as $\mathbf{9 9 - 1 0 3}$ have been prepared ${ }^{88}$ as domains for binding quinone, which play a key role in the photosynthetic energy conversion. Complexation of $p$ benzoquinone by the macrocycles was investigated using ${ }^{l} \mathrm{H}$ NMR titrations. The limiting change in chemical shift observed for the $1: 1$ complexes support the structure shown in the Fig. 3. The signals due to amide protons show $\sim 1$ ppm downfield shifts characteristic of hydrogen bonding and the signals due to the quinone protons show $\sim 2.5 \mathrm{ppm}$ upfield shifts, which indicate that they lie over the host side walls.

A lipophilic glucose derivative is known to form a mul-

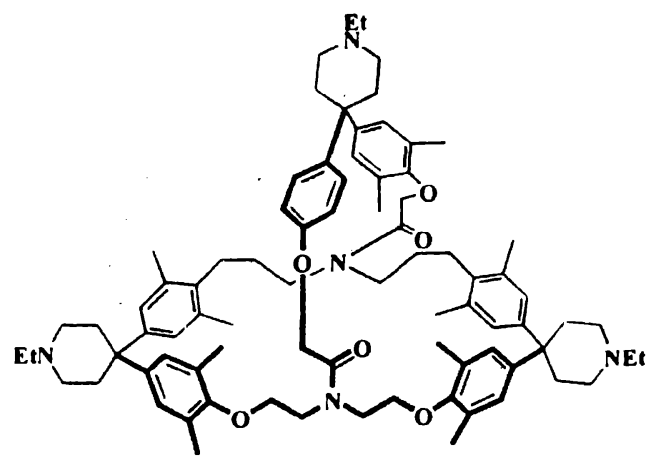

98

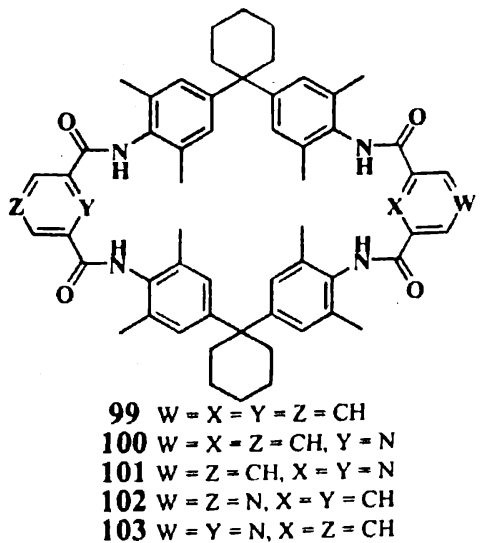

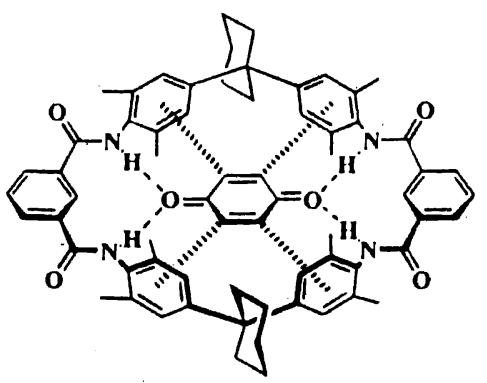

Fig. 3

tiple hydrogen bonded 1:1 inclusion complex with a cholaphane host 104 having a significantly large internal cavity ${ }^{89}$.

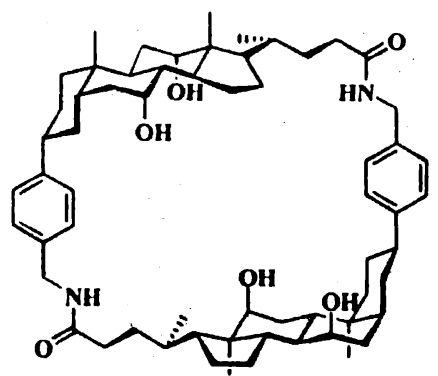

104 
Aliphatic mono(poly)ols and even hydrocarbon adamantane can be bound as guests to well designed cyclophane hosts in water as trans-1,4-cyclohexanediol, trans-1,4-cyclohexanedicarboxylic acid, and adamantanecarboxylic acid bind to host $\mathbf{1 0 5}^{-90}$.

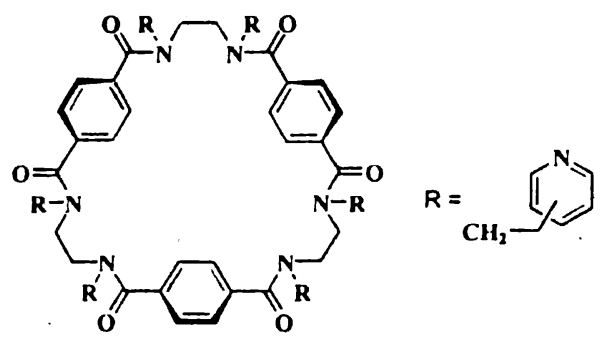

105

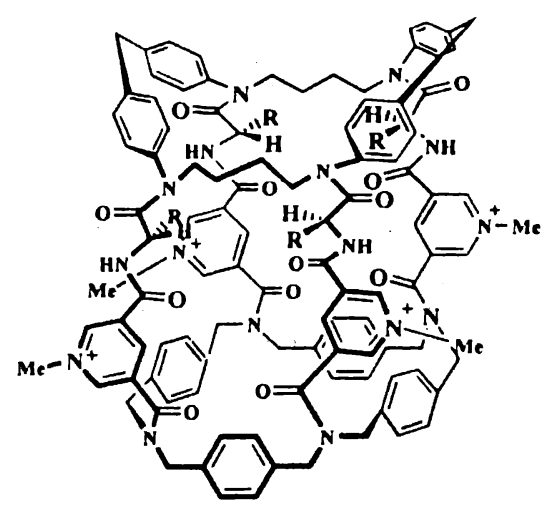

$(+)-106$

Cage like host 106 is an example of chiral hosts having $\mathrm{L}$ - or D-valine moieties as chiral building blocks. This host binds steroid harmones such as $\alpha$-estradiol, $\beta$-estradiol and estratriol enatioselectively in water-methanol $(75: 25)^{91}$. Testosterone having no aromatic moiety can not be bound to host 106.

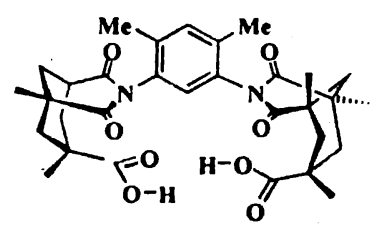

107

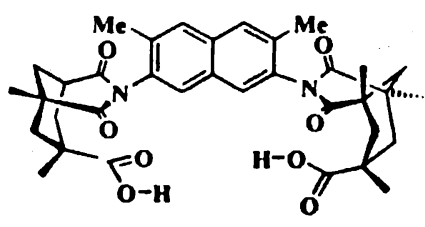

108

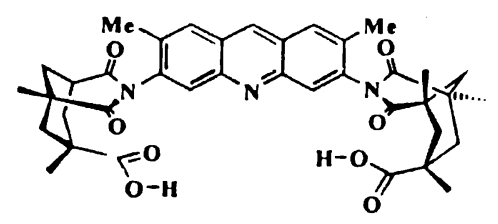

109

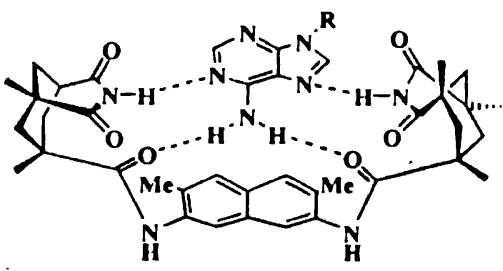

109 Adenine

Rebek has prepared a versatile series of rigid C-shaped tweezer hosts such as $\mathbf{1 0 7 - 1 0 9 ^ { 9 2 }}$. The imide tweezer host 109 forms $1: 1$ complex with adenine and is able to extract adenine, and even nucleosides such as adenosine and deoxyadenosine, from aqueous solution and transport them across liquid organic membranes.

One of the most effective early designs for guest inclusion via hydrogen bonding was reported by Chang and Hamilton ${ }^{93}$. Recognising the possibility of multiple interactions offered by the barbiturate family 110 they designed the complementary macrocyclic host $\mathbf{1 1 1}$ and its acyclic analogue 112. NMR solution complexation studies in chloroform indicated the selective binding of the barbital $110 \mathrm{~b}$ over bulky 110d.

The complexation via complementary hydrogen bonds of three novel ferrocene receptors 113-115 with barbital $110 b$, ethylene urea 116 and tirmethylene urea 117 is described $^{94}$ and the binding mode shown in the Fig. 4 is derived from NMR and X-ray studies.

6-Aryl-2,4-(acyldiamino)-s-triazines 118 constitute hosts<smiles>[R]N1C(=O)N([2H])C(=O)C([R1])([R1])C1=O</smiles>

(a) $R^{\prime}=R^{2}=R^{3}=H$ (b) $R^{1}=R^{2}=E t, R^{3}=H$ (c) $R^{1}=E$ t, $R^{2}=P h, R^{3}=H$ (d) $R^{\prime}=$ Et, $R^{2}=P h, R^{3}=M k$

110 


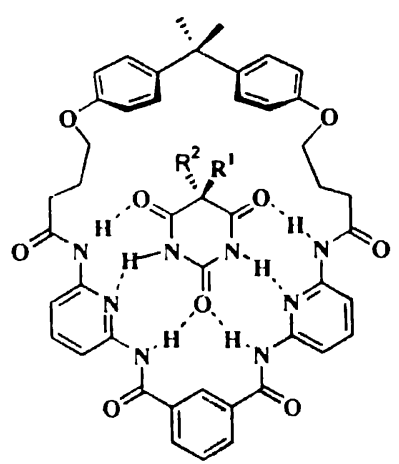

$111,110 \mathrm{a}-\mathrm{c}$<smiles>[R]Nc1cccc(NC(=O)c2cccc(C(=O)Nc3cccc(N[Y])n3)c2)n1</smiles>

$\mathrm{R}=\mathrm{CO}\left(\mathrm{CH}_{2}\right)_{2} \mathrm{Me}$

112 for flavins 119 as depicted in Fig. $5^{95}$. In these synthetic hosts, systematic variation of the spatially remote substituents on the 6-aryl ring alters the hydrogen bond-donating abilitıes of the amide functionality and the hydrogen bonding accepting properties of the triazine- $\mathrm{N}$.

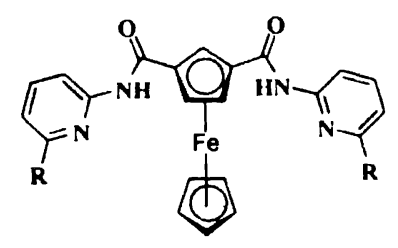

$113 \mathrm{R}=\mathrm{CH}$

$114 \mathrm{R}=\mathrm{NH}$

$115 \mathrm{R}=\mathrm{HNCOE}$

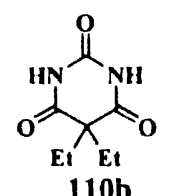<smiles>O=C1CCCN1</smiles><smiles>O=C1CCCCN1</smiles>

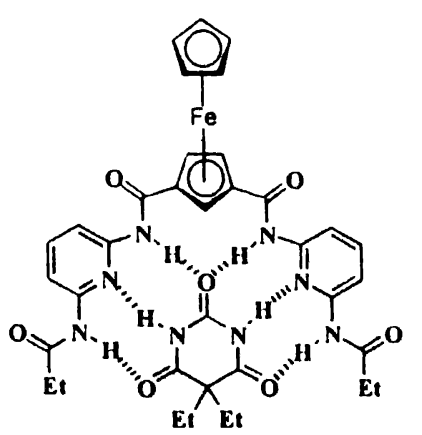

Fig. 4

The binding mode of the host $N, N^{\prime}$-bis(6pivalamidopyrid-2-yl)-3,5-pyridine dicarboxamide 120 to

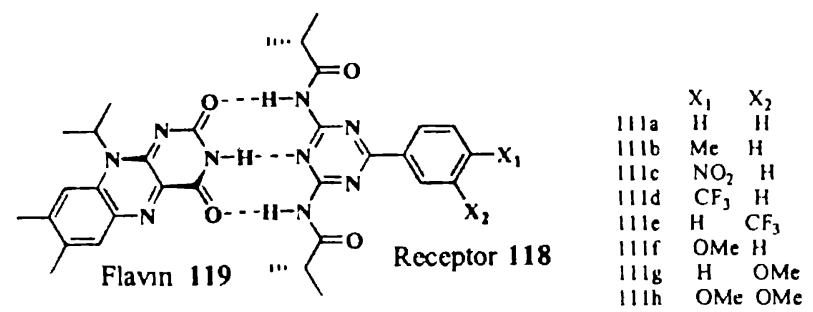

Fig. 5

three different ruthenium complexes with an attached barbituric acid and barbital moieties 121-123 has been studied in chlorinated solvents by NMR and fluorescence titrations ${ }^{96}$. Significant binding was only observed between $\mathbf{1 2 0}$ and $\mathbf{1 2 2}$ series while steric hinderance significantly diminished binding between 120 and 121 or $\mathbf{1 2 3}$.<smiles>CC(C)(C)C(=O)Nc1cccc(NC(=O)c2cccc(NC(=O)c3cncc(NC(=O)C(C)(C)C)n3)n2)n1</smiles>

120

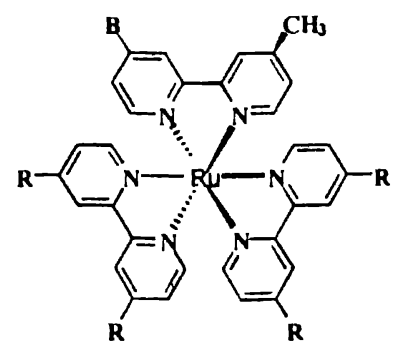<smiles>CC(C)=C1C(=O)NC(=O)NC1=O</smiles><smiles>CC(C)C(=O)C1(C(C)(C)C)C(=O)NC(=O)NC1=O</smiles>

122<smiles>CC(C)C(=O)C1(C(C)(C)C)C(=O)NC(=O)NC1=O</smiles>

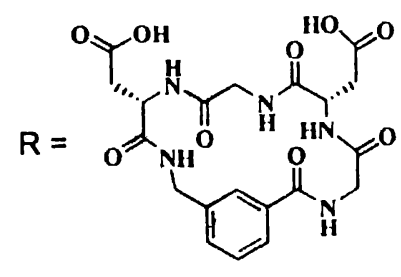


Synthetic receptor $\mathbf{1 2 4}$ has been found via fluorescence titration to compete effectively with cytochrome c peroxidase for binding cytochrome $\mathrm{c}$ forming $1: 1$ complex $^{97}$. Chiral imidazole cyclophane receptors 125 exhibit good chiral recognition toward the enantiomers of $\mathrm{L}$ - and D-amino acid derivatives in chloroform ${ }^{98}$.

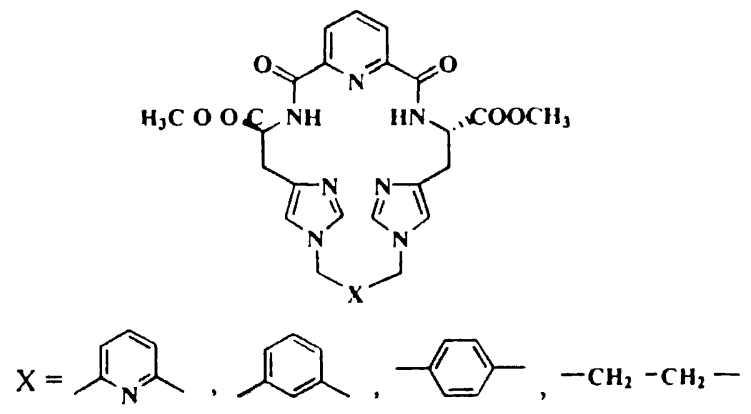

125

Encapsulation of guests in self-assembled tetraurea calix[4]arene $\mathbf{1 2 6}$ and $\mathbf{1 2 7}$ dimers in organic solvents has been probed by PGSE NMR technique ${ }^{99}$.

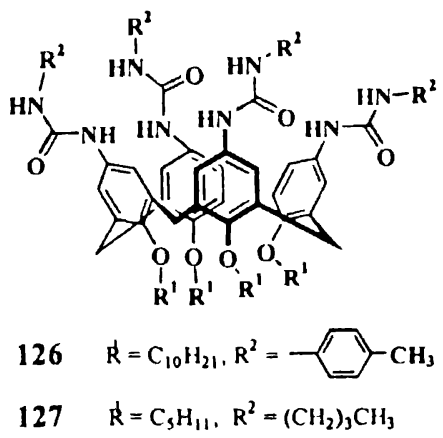

New polypyridine-macrocyclic receptors $\mathbf{1 2 8 - 1 3 0}$ for glucopyranoside recognition were designed and synthesized $^{100}$. The receptors possess a terpyridine skeleton as a hydrogen-bonding site and a flexible polyoxyethylene chain as a bridge for the macrocyclic structure, in which the cavity of the receptor is large enough to incorporate pyranosides. The receptors showed high affinities for $n$-octyl- $\beta$-(D)glucopyranoside, and selective binding of the receptors was observed between epimeric pyranosides.

A new rationally designed receptor molecule 131 binds adrenaline derivatives in water. Its binding pattern imitates the interplay of non-covalent interactions operating in the nature. High shape selectivity is achieved for the slim dopamine skeleton, and leads to the rejection of substrates with an $\alpha$-substituent, such as amino acid derivatives ${ }^{101}$.
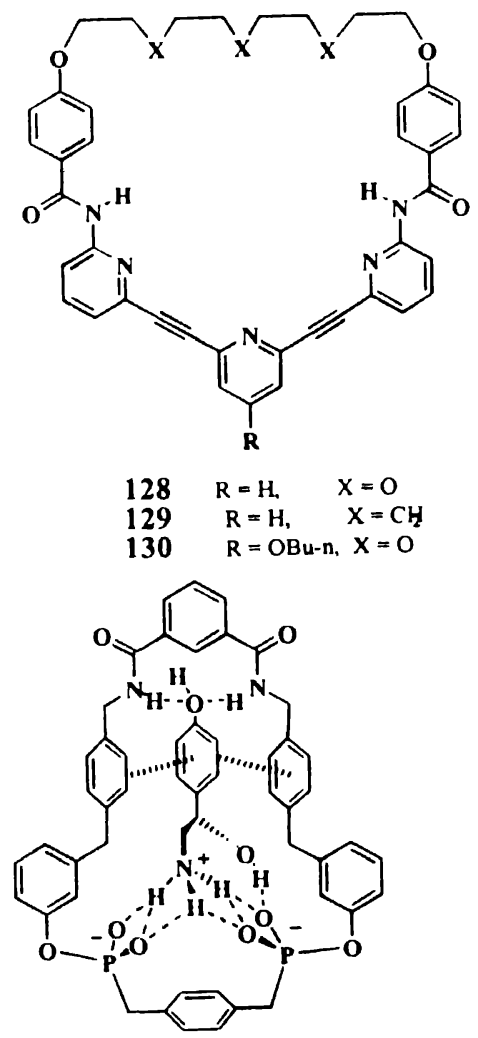

131

\section{Conclusion}

Thus, the pre-eminent role of amide and urea moieties in recognition of both electron-rich (anions and neutral molecules) and electron deficient (cations and neutral molecules) guest species exemplified here points to the scope of exploration of abiotic receptors of these categories for evolving sensors and new models for recognition.

\section{Acknowledgement}

We thank U.G.C., and I.N.S.A., New Delhi for the financial assistance.

\section{References}

1. (a) S. M. Roberts (ed.), "Molecular Recognitıon-Chemical and Biochemical Problems", Royal Society of Chemistry, Cambridge, 1989; (b) H. Dugas, "Bıoorganıc Chemıstry", Sprınger, Berlin, Heidelberg, 1981, p.1; (c) E. Katchalski-Katzir in "Design and Synthesis of Organic Molecules based on Molecular Recognition", ed. G. Van Binst, Springer, New York, 1986, p. 1; (d) J. M. Lehn, "Supramolecular Chemistry", VCH, Weinheim, 1995.

2. D. Hamilton in "Bioorganıc Chemistry Frontiers", ed. H. Dugas, Springer, Berlın, Heidelberg, 1991, Vol. 2. p. 115.

3. C. Moore and B. C. Presssman, Biochem. Biophys. Res 
Commun., 1964, 15, 562.

4. B. Braden, J. A. Hamilton, M. N. Sabesan and L. K. Steinrauf, J. Am. Chem. Soc., 1980, 102, 2704.

5. P. Wipf, S. Venkatraman, C. P. Miller and S. J. Geib, Angew. Chem. Int. Ed. Engl., 1994, 33, 1516.

6. C. J. Pederson, J. Am. Chem. Soc., 1967, 89, 2495.

7. F. Vögtle (ed.), "Comprehesive Supramolecular Chemistry", Pergamon, Elsevier Science Ltd., 1996, Vol. 2, pp. 30-46.

8. A. L. Lehninger, "Principles of Biochemistry", Worth Publishers, New York, 2000.

9. D. Ammann, E. Pretsch and W. Simon, Tetrahedron Lett., 1972, 2473.

10. D. Erne, D. Ammann, A. F. Zhukov, F. Behm, E. Pretsch and W. Simon, Helv. Chim. Acta, 1982, 65, 538.

11. E. Metzger, D. Ammann, A. Asper and W. Simon, Anal. Chem., 1986, 58, 132.

12. E. Metzger, R. Dohner, W. Simon, D. J. Vonderschmitt and K. Gautschi, Anal. Chem., 1987, 59, 1600.

13. M. Bochenska, J. F. Biernat and J. S. Bradshaw, J. Inclusion Phenom. Mol. Recognit. Chim., 1991, 10, 19.

14. E. Pretsch, D. Ammann, H. F. Osswald, M. Guggi and W. Simon, Helv. Chim. Acta, 1980, 63, 191.

15. V. Schefer, D. Ammann, E. Pretsch, U. Oesch and W. Simon, Anal. Chem., 1986, 58, 2282.

16. T. Rosatzin, P. Holy, K. Seiler, B. Rusterholz and W. Simon, Anal. Chem., 1992, 64, 2029.

17. (a) T. Pigot, M. C. Duriez, C. Picard, L. Cazaux and P. Tisnes, Tetrahedron, 1992, 48, 4359; (b) T. Pigot, M. C. Duriez, L. Cazaux, C. Picard and P. Tisnes, J. Chem. Soc., Perkin Trans. 2, 1993, 221.

18. O. Meth Cohn and D. I. Smith, J. Chem. Soc., Perkin Trans. 1, 1982, 261.

19. (a) K. Hiratani, K. Taguchi, K. Ohashi and H. Nakayama, Chem. Lett., 1989, 2070; (b) K. Hiratani and K. Taguchi, Chem. Lett., 1990, 725.

20. D. Siswanta, M. Kin, H. Hisamoto and K. Suzuki, Chem. Lett., 1996, 1011.

21. S. Sasaki, T. Amano, S. Ozawa, T. Masuyama, D. Citterio, H. Hisamoto, H. Hori and K. Suzuki, J. Chem. Soc., Perkin Trans. 1, 2001, 1366.

22. T. W. Bell, H. Choi and G. Heil, Tetrahedron Lett., 1993 , 34, 971 .

23. (a) M. Zinic, B. Bosnic-Kasnar and D. Kolbah, Tetrahedron Lett., 1980, 21, 1265; (b) M. Zinic and V. Skariv, J. Org. Chem., 1988, 53, 2582.

24. C. Cazaux, M. C. Duriez, C. Picard and P. Tisnes, Tetrahedron Lett., 1998, 30, 1369.

25. T. Pigot, M. C. Duriez, C. Picard, L. Cazaux and P. Tisnes, Tetrahedron, 1992, 48, 4359.

26. (a) C. D. Hall, J. H. R. Tucker and N. W. Sharpe, Orgnometallics, 1991, 10, 1727; (b) C. D. Hall, J. H. R.
Tucker, A. G. Shevidan, S. Y. F. Chu and D. J. Williams, J. Chem. Soc., Dalton Trans., 1992, 3133.

27. E. Kimura, R. Machida and M. Kodama, J. Am. Chem. Soc., 1984, 106, 5497.

28. W. Clegg, P. J. Cooper, K. I. Kinner, D. J. Rushton and J. C. Lockhart, J. Chem. Soc., Perkin Trans. 2, 1993, 1259.

29. S. Shinkai, T. Nakaji, Y. Nishida, T. Ogama and O. Manabe, J. Am. Chem. Soc., 1980, 102, 5860.

30. S. Shinkai, Y. Honda, Y. Kusano and O. Manabe, J. Chem. Commun., 1982, 848.

31. (a) R. Kataky, P. E. Nicholson and D. Parker, Tetrahedron Lett., 1989, 30, 4559; (b) J. Chem. Soc., Perkin Trans. 2, 1990, 321; (c) R. Kataky, P. E. Nicholson, D. Parker and Ar. K. Corington, Analyst, 1992, 116, 135.

32. P. D. Beer, E. L. Tite and A. Ibbotson, J. Chem. Soc., Dalton Trans., 1990, 2691.

33. S. Kumar, R. Saini and H. Singh, Tetrahedron Lett., 1992, 33, 7937.

34. S. Kumar, R. Singh and H. Singh, J. Chem. Soc., Perkin Trans. 1, 1992, 3049.

35. (a) S. Kumar, R. Singh and H. Singh, Bioorganic \& Medicinal Chemistry Lett., 1993, 3, 363; (b) S. Kumar, M. S. Hundal, N. Kaur, R. Singh, H. Singh, G. Hundal, M. M. Ripoll and J. S. Aparicio, J. Org. Chem., 1996, 61, 7819; (c) S. Kumar, N. Kumar and H. Singh. Tetrahedron, 1996, 42, 13483.

36. A. Casnati, S. Barboso, H. Rouquette, M. J. SchwingWeill, F. Arnaud-Neu, J. Francois and R. Ungaro, J. Am. Chem. Soc., 2001, 123, 12182.

37. S. Kumar, D. Paul and H. Singh, J. Inclusion Phenomena and Macrocyclic Chemistry, 2000, 37, 371.

38. P. D. Beer, M. G. B. Drew and M. I. Ogden, J. Chem. Soc., Dalton Trans., 1997, 1489.

39. M. B. Inoue, F. Medrano, M. Inoue, A. Raitsimring and Q. Feranando, Inorg. Chem., 1997, 36, 2335.

40. G. R. L. Cousins, R. L. E. Furlan, Y. Fai, J. E. Redman and J. K. M. Sanders. Angew. Chem., 2001, 40, 423.

41. D. S. Marlin and P. K. Mascharak, Chem. Soc. Rev., 2000, 29, 69.

42. (a) L. Fabbrizzi, M. Licchelli, P. Pallavicini, A. Parotti and D. Sacchi, Angew. Chem. Int. Ed. Engl., 1994, 33, 1975; (b) L. Fabbrizzi, M. Licchelli, P. Pallavicini, A. Parotti, A. Taglieti and D. Sacchi, Chem. Eup. J., 1996, 2, 75.

43. T. Gunnlaugsson, B. Bichell and C. Nolan, Tetrahedron Lett., 2002, 43, 4989.

44. J. Strauss and J. Daub, Org. Lett., 2002, 4, 683.

45. J-A. Chen, J-L. Lai, G. H. Lee, Y. Wang, J. K. Su, H-C. Yeh, W-Y. Lin and M-K. Leung, Org. Lett., 2001, 3, 3999.

46. F. Unob, Z. Asfari and J. Vicen, Tetrahedron Lett., 1998, 39, 2951.

47. R. A. Rascal, J. Spergel and D. V. Engbersen, Tetrahedron 
Kumar et al. : Role of amide and urea moieties in molecular recognition

Lett., 1986, 27, 4099.

48. (a) S. Valiyaeetil, J. F. J. Engbersen, W. Verboom and D. N. Reinhoudt, Angew. Chem., 1993, 105, 942;.(b) Angew. Chem. Int. Ed. Engl., 1993, 32, 900.

49. C. Raposo, N. Perez, M. Almaraz, M. L. Mussons, M. C. Caballero and J. R. Moren, Tetrahedron Lett., 1995, 36, 3255.

50. A. P. Bisson, V. M. Lynch, M. K. C. Monahan and E. V. Anslyn, Angew. Chem. Int. Ed. Engl., 1997, 36, 2340.

51. T. R. Kelley and M. H. Kim, J. Am. Chem. Soc., 1994, 116, 7072 .

52. P. Builmann, S. Nishizawa, K. P. Xiao and Y. Umezawa, Tetrahedron, 1997, 53, 1647.

53. P. D. Beer, Z. Chen, A. J. Goulden, A. R. Graydon, S. E. Stokes and T. Wear, J. Chem. Soc., Chem. Commun., 1993, 1834.

54. P. D. Beer, A. R. Graydon, A. O. M. Johnson and D. K. Smith, lnorg. Chem., 1997, 36, 2112.

55. A. Jurius, V. Balzani, F. Barigeletti, S. Campagna, P. Belser and A. von Zelewsky, Coord. Chem. Rev., 1998, 84, 85 .

56. P. D. Beer, Acc. Chem. Res., 1998, 31, 71.

57. F. Szemes, D. Hesek, Z. Chen, S. W. Dent, M. G. B. Drew, A. J. Goulden, A. K. Graydon, A. Grieve, R. J. Mortimer, T. Wear, J. S. Weightman and P. D. Beer, Inorg. Chem., 1996, 35, 5868.

58. P. D. Beer, S. W. Dent and T. Wear, J. Chem. Soc., Dalton Trans., 1996, 2341.

59. S. Watanabe, O. Onogawa, Y. Komatsu and K. Yoshida, $J$. Am. Chem. Soc., 1998, 120, 229.

60. P. D. Beer, V. Timoshenko, M. Maestri, P. Passaniti and V. Balzani, Chem. Commun., 1999, 1755.

61. K. Kavallieratos, C. M. Berato and R. H.

62. M. P. Hughes and B. D. Smith, J. Org. Chem., 1997, 62, 4492.

63. P. D. Beer, P. K. Hopkins and J. D. McKinney, Chem. Commun., 1999, 1253.

64. C. R. Bondy, P. A. Gale and S. J. Loeb, Chem. Commun., $2001,729$.

65. Corey P. Causey and William E. Allen, J. Org. Chem., 2002, 67, 5963.

66. (a) P. A. Gale, S. Camiolo, C. P. Chapman, M. E. Light and M. B. Hursthouse, Tetrahedron Lett., 2001,42, 5095; (b) P. A. Gale, S. Camiolo, G. J. Tizzard, C. P. Chapman, M. E. Light, S. J. Coles and M. B. Hursthouse, J. Org. Chem., 2001, 66, 7849.

67. K. Navakhum, P. A. Gale, S. Camiolo, M. E. Light and M. B. Hursthouse, Chem. Commun., 2002, 2084.

68. P. Piatek and J. Jurczak, Chem. Commun., 2002, 2450.

69. K. Choi and A. D. Hamilton, J. Am. Chem. Soc., 2001, 123, 2456.
70. A. D. Hamilton in "Advances in Supramolecular Chemistry", JAI Press, Greenwich, CT, 1900, Vol. 1, 1.

71. J. Rebek (Jr.), Acc. Chem. Res., 1990, 23, 399.

72. S. S. Yoon and W. C. Still, J. Am. Chem. Soc., 1993, 115, 823.

73. M. M. Conn, G. Deslongchamps, J. de Mendoza and J. Rebek, J. Am. Chem. Soc., 1993, 115, 3548.

74. J. C. Adrian and C. S. Wilcox, J. Am. Chem. Soc., 1989, 111, 8055; T. H. Webb and C. S. Wilcox, Chem. Soc. Rev. 1993, 383.

75. T. W. Bell, P. J. Cragg, M. G. B. Drew, A. Firestone, A. D. I. Kwok. J. Liu, R. T. Ludwig and A. T. Papoulis, Pure Appl. Chem., 1993, 65, 361.

76. W. L. Mock, Top. Curr. Chem., 1995, 175, 1.

77. F. Garcia-Tellado, S. Goswami, S. K. Chang, S. Geib and A. D. Hamilton, J. Am. Chem. Soc., 1990, 112, 7393.

78. F. Behm, W. Simon, W. M. Müller and F. Vogtle, Helv. Chim. Acta, 1985, 68, 940; F. Vögtle, H. Puff, E. Friendrichs and W. M. Müller, J. Chem. Soc., Chem. Commun., 1982, 1398.

79. F. Ebmeyer and F. Vögtle, Angew. Chem. Int. Ed. Engl. 1989, 28, 79.

80. (a) C. Sell and F. Vögtle, Angew. Chem. Int. Ed. Engl., 1991, 30, 442; (b) F. Vögtle and R. Hoss, J. Chem. Soc., Chem. Commun., 1992, 21, 1584; R. Hoss and F. Vögtle, Chem. Ber., 1993, 126, 1003.

81. L. Wambach and F. Vögtle, Tetrahedron Lett., 1985, 26, 1483; B. Dung and F. Vögtle, J. Inclusion Phenom. Mol. Recognit. Chem., 1988, 6, 429; J. Breitenbach, K. Rissanen, U. U. Wolf and F. Vögtle, Chem Ber., 1991, 124, 2323.

82. K. C. Chapman and W. C. Stıll, J. Am. Chem. Soc., 1989, 111, 3075; R. Liu and W. C. Still, Tetrahedron Lett., 1993, 34, 2573.

83. J. D. Kilburn, A. R. MacKenzie and W. C. Still, J. Am. Chem. Soc., 1988, 110, 1307.

84. P. E. J. Sanderson, J. D. Kilburn and W. C. Still, J. Am. Chem. Soc., 1989, 111, 8314.

85. B. C. Askew, Tetrahedron Lett., 1990, 31, 4245.

86. F. Diederich and K. Dick, Angew. Chem. Int. Ed. Engl., 1984, 23, 810.

87. F. Diederich and K. Dick, J. Am. Chem. Soc., 1984, 106, 8024.

88. (a) C. A. Hunter, J. Chem. Soc., Chem. Commun., 1991, 749; (b) J. Am. Chem. Soc., 1992, 114, 5303.

89. R. P. Bonar-Law, A. P. Davis and B. A. Murray, Angew. Chem. Int. Ed. Engl., 1990, 29, 1407.

90. F. Vögtle and W. M. Müller, Angew. Chem. Int. Ed. Engl., $1984,23,712$.

91. Y. Murakami, O. Hayashida, T. Ito and Y. Hisaeda, Chem. Lett., 1992, 497. 


\section{J. Indian Chem. Soc., Vol. 80, December 2003}

92. J. Rebek (Jr.), Angew. Chem. Int. Ed. Engl., 1990, 29. 245.

93. S. K. Chang and A. D. Hamilton, J. Am. Chem. Soc., $1988,110,1318$.

94. S. R. Callinson, T. Gelbrich, M. B. Hursthouse and J. H. R. Tucker, Chem. Coinmun., 2001, 555.

95. R. Deans, G. Cooke and V. M. Rotello, J. Org. Chem., 1997, 62, 836 .

96. T. Chin, Z. Gao, I. Lelouche, Y. K. Shin, A. Purandarare, S. Knapp and S. S. Isied, J. Am. Chem. Soc., 1997, 119 , 12849.
97. Y. Wei, G. L. McLendon, A. D. Hamilton, M. A. Case, C. B. Purring, Q. Lin, H. S. Park, C. S. Lee and T. Yu, Chem. Commun., 2001, 1580.

98. J. S. You, X. Q. Yu, G. L. Zhang, Q. X. Xiang, J. B. Lan and R. G. Xie, Chem. Commun., 2001, 1816.

99. L. Frish, S. E. Mathews, V. Böhmer and Y. Cohen, J. Chem. Soc., Perkin Trans. 2, 1999, 669.

100. M. Inouye, J. Chiba and H. Nakazumi, J. Org. Chem., $1999,64,8170$.

101. M. Herm, O. Molt and T. Schreder, Angew. Chem. Int. Ed. Engl., 2001, 17, 3148. 